Л. Л. Мацепура

\title{
ФОРМУВАННЯ ТА РОЗВИТОК ПРАВИЛЬНОЇ ІНШОМОВНОЇ ЗВУКОВИМОВИ В ДІТЕЙ ДОШКІЛЬНОГО ВІКУ
}

Мацепура Л. Л. Формування та розвиток правильної іншомовної звуковимови в дітей дошкільного віку.

У статті розглядається питання формування та розвитку правильної іншомовної звуковимови в дітей дошкільного віку, подається характеристика звуків англійської мови, навчання іншомовної вимови.

Ключові слова: мовленнєва діяльність, інтонаційні моделі, фонетичні навички, артикуляційний апарат, фонетична зарядка.

Мацепура Л. Л. Формирование и развитие правильного иноязычного звукового произношения у детей дошкольного возраста.

В статье рассматриваются вопросы формирования и развития правильного иноязычного произношения у детей дошкольного возраста, дается характеристика звуков английского языка, обучение иностранному произношению.

Ключевые слова: речевая деятельность, интонационные модели, фонетические навыки, артикуляционный аппарат, фонетическая зарядка. 
Matsepura L. L. The formation and development of correct foreign proununciation in the children under school age.

The article deals with the formation and development of foreign pronunciation of the children under school age, it is the characteristic of English sounds, a training of foreign pronunciation.

Key words: speech activity, the model of intonation, phonetic skills, the articulation apparatus.

Мовленнєва діяльність в усній та письмовій формі охоплює необхідні складові: автоматизовані компоненти - навички (фонетичні, граматичні, лексичні). Вони входять до мовної компетенції. Формування цих навичок є головним завданням під час навчання говоріння, слухання, письма та читання. Кожен вид навичок має свою специфіку, тому успішне їх формування потребує окремих підходів, спеціальних методів та прийомів.

Кожна мова має свої вимовні норми. Не можна вивчити мову, не оволодівши звуковимовою. Сучасні дослідження доводять (А. М.Богуш, Є. М. Верещагін, І. О. Зимня, Е. І. Негневицька, Л. М. Паламар, О. В. Паскаль, Ю. І. Пасов, М. І. Пентилюк, В. А. Трунова, Л. В. Щерба та ін.), що вимова є базовою характеристикою мовлення, грунтом для розвитку й удосконалення всіх інших навичок рідного й іншомовного мовлення.

Вимовні навички є досить специфічними. За належністю до видів діяльності їх відносять до рухово-мовленнєвих. Оскільки мовленнєві одиниці існують тільки у звукових образах, вимовна навичка, з одного боку, злита з лексичними навичками, де вона за своїм характером мовленнєва; 3 іншого боку, своїм функціонуванням вона зобов'язана рухам органів мовлення, тому ця навичка - рухова (Ю. Пасов). Слуховимовні навички $є$ складними, оскільки відрізняються поступовістю в розвитку. На початковому етапі навчання формуються перш за все навички правильної вимови звуків виучуваної мови, складається відповідна артикуляційна база, усвідомлюються й застоюються одночасно звукові труднощі, пов'язані 3 інтерференцією (негативний перенос) рідної мови.

Учені довели, що повноцінне засвоєння звукової системи виучуваної мови забезпечується мовленнєвим слухом.

«Мовленнєвий слух, із психолінгвістичної точки зору, - це здатність людини при сприйманні мовлення уловлювати слухом i одночасно відтворювати у внутрішній мові всі фонологічні засоби мови, артикулюючи й інтонуючи мовлення, яке вона чує» [1, с. 52]. 
Фонетичний слух (компонент мовленнєвого слуху) - це вміння чути не тільки фонеми рідної мови, але й інші звуки, які реально вимовляються дитиною в рідній чи іноземній мовах. Фонетичний слух можна розвинути до будь-якої ступені тонкості. Умова розвитку фонематичного слуху - це постійне повторення зразка. Головною складовою засвоєння звукового боку мови є чітке розрізнювання звука заданого і звука, який дитина вимовляє реально.

Оволодіння звуками та інтонаційними моделями іноземної мови $\epsilon$ необхідною передумовою розвитку умінь спілкування у всіх видах мовленнєвої діяльності. Лише засвоївши норми вимови, дошкільнята зможуть розуміти висловлювання інших і точно формувати власні.

Метою навчання фонетичного матеріалу $\epsilon$ формування слуховимовних і ритміко-інтонаційних навичок. Під слухо-вимовними навичками мовлення розуміють навички фонемно правильної вимови всіх звуків у потоці мовлення та розуміння всіх звуків при аудіюванні. Ритмікоінтонаційні навички - це навички інтонаційно і ритмічно правильного оформлення мовлення i, відповідно, розуміння мовлення інших людей.

Із цього слідує, що фонетичні навички передбачають як автоматизовану рецепцію звуків (так званий «фонематичний слух») та інтонем (за аналогією з фонематичним - «інтонаційний слух»), так і їх (ре)продукцію - артикуляцію та інтонування.

Усі навички вимови (так само граматичні та лексичні) мають характеризуватися якостями автоматизованості, гнучкості і сталості та формуватися поетапно.

Первинний етап оволодіння другою чи іноземною мовою нагадує процес становлення рідної мови в дитини. Мовленнєвий апарат у дошкільнят дуже гнучкий, вони легко наслідують звуки та звукосполучення рідної та нерідної мов. Існує суттєва різниця між засвоєнням звуків рідної мови і другої чи іноземної.

У процесі засвоєння рідної мови в дитини існує вже розвинутий фонематичний слух, тренований довгим підготовчим періодом. Під час навчання другої, іноземної мови, цієї фонетичної бази немає. Дошкільнята не плутають і не змішують рідну мову з іншою і завжди усвідомлюють, якою саме мовою розмовляють. Вимова закріплюється та зберігається на все життя. Малюки вкрай чутливі до вимови, оскільки особливо сприйнятливі до фонетики та інтонації мовлення.

Певні мовленнєві зразки зберігаються в їхній памяті у вигляді звукових комплексів, пригадуючи, які в тих чи тих ситуаціях, діти ○ Л. Л. Мацепура, 2012. 
керуються переважно власними слуховими уявленнями. При цьому іншомовні мовленнєві зразки сприймаються ними відокремлено від звукових комплексів рідної мови. I якщо, а це дуже важливо, при вивченні нових фонем у дітей сформується неправильна вимова, то пізніше, у школі ії вже дуже важко буде виправити.

Від того, як поставлене навчання вимови, як засвоєна звукова система мови, повністю залежить розуміння мовлення й говоріння. У шкільному віці діти дещо втрачають попередню здатність легко й точно відтворювати звуки іноземної мови. I навіть тоді, коли опиняться в іноземному середовищі й досконало оволодіють чужою мовою - лексичним складом та граматичною будовою, у їхній вимові зберігається акцент рідної мови.

Украй важливо, щоб самі педагоги, які навчають дітей іноземної мови, вільно володіли розмовним мовленням і мали бездоганну вимову, інтонування. Це унеможливить звикання дітей до неправильного вимовляння звуків, слів, фраз нерідною мовою, застереже дорослих від сумної необхідності згодом переучувати, виправляти їх.

Недосконалість дитячого мовленнєвого апарату і зумовлені віком дефекти вимови можуть бути причиною труднощів у роботі вчителя над фонетичною стороною навчання іноземної мови. У випадку, коли дефект мовлення зумовлено не віком, а логопедичними причинами, необхідна консультація спеціаліста (деякі логопеди вважають, що вивчення іноземної мови тільки збільшить мовленнєві проблеми дитини).

Основою будь-якої мови є звук. Усі види мовленнєва діяльність базуються на звуках. Навчання фонетичного матеріалу передбачає оволодіння учнями всіма звуками і звукосполученнями виучуваної іноземної мови, наголосом та основними інтонаційними моделями (інтонемами) найбільш поширених типів простих і складних речень.

Існує кілька критеріїв відбору фонетичного мінімуму. За ступенем складності фонетичного явища об'єктами спеціального засвоєння при навчанні вимови $є$ лише ті, що являють для учнів певні труднощі: за критерієм відповідності потребам спілкування до мінімуму відносять передусім ті звуки та інтонеми, що виконують у мовленні смислорозрізнювальну функцію; за критерієм нормативності 3 фонетичного мінімуму для навчальних закладів вилучаються різні відхилення від норми, а об'єктом навчання виступає повний стиль зразкової літературної вимови; за еталон береться вимова дикторів, коментаторів радіо і телебачення. 
За ознакою схожості / розбіжності звуків англійської та рідної мов усі звуки іноземної мови умовно розділяють на три групи.

До першої групи відносять звуки, максимально наближені до звуків рідної (української) мови за акустичними особливостями та артикуляцією $([b, m, s, z]$,$) .$

Формування навичок вимови названих звуків не викликає особливих труднощів, оскільки має місце позитивний перенос навичок $з$ рідної мови в іноземну. Для засвоєння цих звуків можна обмежитися імітацією, ніяких інших вправ ця група не потребує.

Друга група включає звуки, які, на перший погляд, дуже схожі на звуки рідної мови, але відрізняються від них за суттєвими ознаками $([e, I, i, l])$.

Сприймання та відтворення звуків, що належать до другої групи, характеризується високим ступенем інтерференції. Учні автоматично переносять навички вимови цих звуків з рідної мови в іноземну, що призводить не тільки до появи акценту в мовленні, але й до помилок на рівні змісту. Звуки цієї групи вимагають від учителя посиленої уваги та спеціального тренування в різноманітних вправах, особливо в тих, де $\epsilon$ контрастування з відповідними звуками рідної мови.

До третьої групи належать звуки, які не мають артикуляційних або акустичних аналогів у рідній мові учнів $([w, r, h])$. Звуки цієї групи також викликають значні труднощі при засвоєнні, тому що має місце формування абсолютно нової артикуляційної бази.

Таким чином, належність звука іноземної мови до тієї чи іншої 3 трьох згаданих груп зумовлює методику його засвоєння - способи ознайомлення учнів з ним, вибір і кількість вправ, що потрібні для оволодіння даним звуком у рецепції та (ре)продукції.

При навчанні іншомовної вимови слід ураховувати, що учні вже володіють звуковими засобами рідної мови. 3 одного боку, це допомагає в оволодінні вимовою нової (іноземної) мови, 3 іншого викликає певні труднощі, спричинені інтерференцією рідної мови. Так, типовою помилкою для україномовних та російськомовних учнів $\epsilon$ недотримання довготи голосних в англійській мові, бо в рідній мові довгота не має смислорозрізнювального характеру.

Джерелом помилок в інтонації $\epsilon$, наприклад, відсутність в українській і російській мовах високого початку та різкого падіння у спадному тоні, що характерно для англійського мовлення. Отже, у плані навчання вимови вчитель повинен скоректувати ті фонетичні 
навички, що вже $є$ в учнів, у відповідності до фонетичної системи нової мови і доповнити іiі тими елементами вимови, які відсутні в рідній або другій мові учнів.

Для нейтралізації негативного впливу фонетичних навичок рідної мови робота 3 вивчення іншомовної вимови має будуватися на основі порівняльного аналізу фонологічних систем рідної та іноземної мов, що $є$ одним із важливих спеціальних принципів навчання фонетичного матеріалу. Це дозволяє передбачити можливі труднощі і тим самим знайти шляхи їх подолання, які визначатимуть характер пояснень учителя та вправи, що будуть застосовуватися в навчальному процесі.

У зв'язку з тим, що репродукція звукового потоку обов'язково супроводжується контролем з боку слухового аналізатора, у пам'яті того, хто говорить мають бути наявні відповідні акустичні образи. Це вимагає одночасного створення слухових (акустичних) та мовленнєво моторних образів слів.

Ураховуючи труднощі, з якими стикається учень при оволодінні вимовою іноземної мови, у процесі навчання доцільно використовувати імітативний та аналітичний методи одночасно (пояснення та аналіз слід застосовувати в такому обсязі, у якому вони можуть бути корисні учням для розуміння особливостей фонетичного явища і полегшення його засвоєння). Такий метод одержав назву аналітико-імітативного.

Доведено, що діти краще засвоюють вимову будь-якого звука в конкретному певному слові. Уводячи нове слово або мовленнєвий зразок, треба декілька разів вимовити його, потім дітям запропонувати повторити хором. Тільки після цього викладач перевіряє вимову кожного. Діти повинні не тільки правильно імітувати мовлення викладача, але й звертати увагу на недоліки у вимові своїх товаришів. Основний прийом у роботі над вимовою на цьому етапі - імітація, багаторазове повторювання мовленнєвих зразків і їхніх компонентів. Діти дошкільного віку гарно імітують, а мову педагога сприймають як взірець, тому вона повинна бути внормованою й емоційною, а звуки мови будуть сприйматися правильніше, якщо діти побачать, як вони артикулюються.

Робота над формуванням фонетичних навичок відбувається на спеціальному етапі заняття: фонетичній зарядці. Кожне заняття бажано починати з фонетичної зарядки, яка полягає в тому, що діти вимовляють окремі звуки, слова, у які ці звуки входять, називають уже вивчені предмети, повторюють вірші, лічилки тощо. Якщо діти 
припускаються помилок у вимові, то педагог показує їм, як подібні помилки ведуть до зміни значення слова (ship - sheep, pen - pan).

Корисним у процесі навчання вимови може бути магнітофон. Педагог може записати, наприклад, читання віршів дітьми, щоб потім вони могли прослухати своє читання, порівняти його зі зразком, а педагогу буде легше проаналізувати вимовні помилки дітей і потім виправити їх.

Хорове заучування текстів і хорові відповіді на запитання, $\epsilon$ хорошим засобом засвоєння інтонації.

Проте інколи викладач, намагаючись чітко вимовити слово, речення, вимовляє його дуже повільно, тому сам неправильно акцентує слова. Під час хорової відповіді ця помилка закріплюється. У хоровій роботі треба слідкувати за ритмом, наголосом, мелодією, інтонацією. Інтонаційні структури англійської та української мов мають два базові тони - висхідний, коли інтонація зростає, та спадний, за якими розрізняють повідомлення і запитання, завершені й незавершені висловлювання.

Учитель, на відміну від дітей, не повинен обмежуватись лише вживанням висхідного та спадного тонів, він має користуватися всією різноманітністю інтонаційних засобів, що існують у певній мові.

Привабливість мовлення вчителя, який виступає для дітей носієм іноземної мови, бажання наслідувати його залежить від їх мовлення, емоційної забарвленості, вживання власне тих засобів виразності, які притаманні англійській мові. Різні емфатичні засоби інтонування речень учні можуть засвоювати шляхом наслідування або користуватися інтонаційними засобами рідної мови.

Навчати, зрозуміло, треба без довгих, нудних пояснень, де повинен бути язик і як треба відкривати рота. Навчання проводиться у вигляді звукоімітаційної гри. Звуки відпрацьовуються як ізольовано, так і в опозиціях: довгі та короткі голосні, міжзубні та свистячі приголосні.

Завдання вчителя підібрати різноманітні форми цієї роботи: артикуляційні вправи («Киця лиже молочко»; робота 3 дзеркалом (для контролю правильності артикуляціi); фонетичні вправи («Плесни в долоні, коли почуєш звук [r]», «Передражни мене», «Зіпсований телефон»); нескладні римовки, скоромовки, пісеньки.

Під час занять у процесі формування слуховимовних навичок важливо звертатися до ігрових моментів. Навчальна мета гри в такому випадку полягає в тому, щоб діти вимовляли і впізнавали вивчені звуки, не думаючи про це спеціально, роблячи це автоматично.

(ㄱ Л. Л. Мацепура, 2012. 
Фонетичні ігри повинні бути різноманітні за своїм характером i, залежно від етапу навчання, поєднуватися з іншими видами ігор. Усі пояснення до проведення гри вчитель повинен надавати рідною мовою.

Педагог контролює процес оволодіння звуковою стороною рідного й іншомовного мовлення, зауважує, які фонетичні явища засвоєні дітьми, а які - ні. Вважати, що дитина засвоїла звук, тип наголосу або інтонації, можна лише за умови, що дитина правильно послуговується ними у своєму мовленні, під час вільного висловлювання своєї думки, а не тільки правильно виконує всі завдання в процесі фонетичної гри.

Організація фонетичної гри. При відпрацюванні слуховимовних навичок у процесі гри необхідно дотримуватися певної послідовності дій, а саме:

1. Спочатку необхідно привернути увагу дітей до виучуваного звука, потім увести новий звук.

2. Якщо необхідно, то пояснити артикуляцію звука.

3. Надати можливість спочатку повторити звук, а потім вимовити його відповідно до ігрового моменту.

4. Навчити розрізняти на слух звуки, що змішуються при вимові, і реагувати на кожний відповідними ігровими діями.

5. Навчити імітувати звукові відмінності в грі.

6. Навчити самостійно вимовляти звуки під час гри.

7. Залучити до гри слова i фрази, які містять звук, що відпрацьовується.

Кількість вправ на навчання вимовлянню залежить від фантазії i бажання вчителя зробити урок незвичним і цікавим. Використання рухів, наочності i пісень зроблять ці вправи ще цікавішими. Формуванню в учнів стійких навичок вимови сприятимуть раціональні способи введення фонетичних явищ та послідовність виконання вправ.

\section{Література}

1. Довгаль В. Я. Фонетичні вправи для навчання та контролю англійської вимови в середньому навчальному закладі / В. Я. Довгаль, О. П. Петращук // Іноземні мови. 1996. - № 4 - C. 72.

2. Методика викладання іноземних мов у середніх навчальних закладах / [кол. авторів під керівн. С. Ю. Ніколаєвої]. - К. : Ленвіт, 2002.

3. Панова Л. С. Методика навчання іноземних мов у загальноосвітніх навчальних закладах : [підручник] / Л. С. Панова, І. Ф. Андрійко, С. В. Тезікова та ін. - К. : ВЦ «Академія», 2010. - 328 с. 
4. Негневицкая Е.И. Обучение английскому языку детей в первом классе / Е. И. Негневицкая, 3. Н. Никитенко, Е. А. Ленская. - М. : МП РСФСР, 1987. - 32 с.

5. Практикум з методики викладання іноземних мов у середніх навчальних закладах / [кол. авторів під керівн. С. Ю. Ніколаєвої]. - К. : Ленвіт, 2004.

6. Савінова Н. В. Коригування мовлення дітей старшого дошкільного віку в ігровій діяльності : автореф. дис. ... канд. пед. наук : спец. 13.00.02 / Н. В. Савінова. Одеса. $-2005 .-21 \mathrm{c}$.

7. Шишкова И. А. Английский для малышей / И. А. Шишкова, М. Е Вербовская. М. : Росмэн, 2006.

Стаття надійшла до редакції 12.10.2012 p. 